\title{
Comparative effect of diets on microbial activity of the rumen in sheep and goats
}

\author{
C. MASSON, W. ALRAHMOUN, B. BELlET, J.L. TISSERAND \\ E.N.S.S.A.A.-I.N.R.A., Laboratoire de Recherches de la Chaire de Zootechnie \\ 26, boulevard $D^{r}$ Petitjean, 21100 Dijon (France)
}

Three 2-year old Alpine castrated he-goats and three 2-year old Charolais castrated rams with rumen fistula were used to study the microbial activity in the rumen. The animals were fed ad libitum twice daily during six weeks (three weeks of adaptation and three experimental weeks). Five diets were studied successively : meadow hay (9.2 p. 100 crude protein); barley straw treated with $\mathrm{NaOH}(3.2$ p. $100 \mathrm{CP})$; barley straw treated with $\mathrm{NaOH}$ and supplemented with urea $(12 \mathrm{~g} / \mathrm{kg}):(7.5 \mathrm{p} .100 \mathrm{CP})$; barley straw treated with $\mathrm{NaOH}$ and supplemented with soya-bean $(120 \mathrm{~g} / \mathrm{kg}) ; 9.6$ p. $100 \mathrm{CP})$; barley straw untreated supplemented by soya-bean $(9.8$ p. $100 \mathrm{CP})$. The main factors measured were : dry matter voluntary intake, water intake, rumen volume (PEG method), cellulolytic activity « in sacco», microbial rumen population (total anaerobic flora, cellulolytic, amylolytic, proteolytic flora and protozoa), the principal biochemical data of rumen liquor $\left(\mathrm{pH}, \mathrm{NH}_{3}-\mathrm{N}, \mathrm{N}_{\mathrm{t}}, \mathrm{VFA}\right.$ ).

Dry matter intake in $\mathrm{g} \mathrm{DM} / \mathrm{kg} \mathrm{P}^{0.75}$ varied between 55 and 74 in goats and 35 and 72 in sheep. Dry matter intake of goats was higher (110 to $140 \mathrm{p}$. 100) than that of sheep and more especially when the protein content of the diet was low.

Water intake in $\mathrm{ml} / \mathrm{g}$ DM varied between 3.1 and 5.5 in goats and 3.9 and 7.2 in sheep, it was lower with the goats $(60$ to $90 \mathrm{p}$. 100).

The treatment with alkali increased the water intake by $56 \mathrm{p} .100$ in the goats and 43 p. 100 in the sheep. The rumen volume was similar in both species.

The cellulolytic activity evaluated «in sacco » was more important in goats than in sheep with the barley straw treated with $\mathrm{NaOH}$ or barley straw supplemented with soya-bean (157 p. 100 and 118 p. 100).

The total VFA concentration of the rumen liquor tended to be higher in goats than in sheep and especially for the barley straw with $\mathrm{NaOH}$ or supplemented with urea.

Nitrogen deficiency (barley straw) significantly reduced the microbial population in sheep and the cellulolytic activity «in sacco», the total VFA were lower in sheep than in goats.

After supplementation of barley straw with soya-bean or urea, the microbial population became again similar to that observed with meadow hay. The treatment with $\mathrm{NaOH}$ decreased the total anaerobic flora (58 p. 100 and 78 p. 100 in sheep and in goats respectively), but increased the total VFA production.

In conclusion these results show that the anaerobic flora of goats support the dietary and especially nitrogen deficiency better than that of sheep.

Key words : Digestion, goat, sheep, rumen, microbial activity, $\mathrm{NaOH}$ treated straw. 